\title{
URGENSI BIMBINGAN KOLABORATIF BAGI ANAK YANG MENGALAMI LEARNING DISABILITIES DI SEKOLAH DASAR
}

\author{
Medina Chodijah \\ UIN Sunan Gunung Djati Bandung, \\ Korespondensi ; J1. Sarimas II No.5 Bandung. 022-7234508, 081931421441
}

\begin{abstract}
Learning disabilities is a wide variety of learning problem which is known more than 100 years ago. No one can help learming disabled children alone.Collaborate is the best way that can maximize they potential and minimize they problems. Many research was conduct to see the effect of the collaborative guidance, and the result shown that collaborative has positif effect to all children aspects. But in Indonesia there still no structurize platform to conduct the collaborative guidance.
\end{abstract}

\section{KEYWORDS}

Collaborative Guidance; Learning Disabilities; Elementary School Children

DOI: https://doi.org/10.15575/saq.v1i2.1430

\section{A. PENDAHULUAN}

Specific learning disabilities atau kesulitan belajar spesifik sudah diketahui sekitar 100 tahun yang lalu. Bahkan sejak tahun 1960 istilah kesulitan belajar digunakan sebagai identifikasi pada anak dengan kesulitan membaca (disleksia), DMO, hambatan persepsi, disfungsi persepsi motorik, gangguan bahasa spesifik serta prestasi belajar rendah dibidang tertentu.

Secara keseluruhan kesulitan belajar pada anak usia sekolah mempunyai insidensi yang bervariasi. DI Indonesia terdapat beberapa penelitian terhadap keberadaan anak berkesulitan belajar antara lain penelitian yang dilakukan terhadap 3.215 murid kelas satu hingga kelas enam SD di DKI Jakarta. Hasil penelitian tersebut menunjukkan bahwa terdapat $16,52 \%$ yang oleh gurunya diperkirakan sebagai murid yang termasuk berkesulitan belajar (Abdurrahman \& Ibrahim, 1994). Sejak tahun 1986, Menteri Pendidikan dan Kebudayaan Indonesia bekerjasama dengan USAID melaporkan bahwa di Indonesia diperkirakan terdapat 300.000 anakanak yang membutuhkan layanan pendidikan khusus (Anak Berkebutuhan Khusus). Jika angka statistik 30\% di Amerika Serikat digunakan, maka di Indonesia pada tahun 1986 diperkirakan terdapat 90.000 anak-anak berkesulitan belajar. Berdasarkan data yang ada di Dinas Pendidikan Kota Bandung bahwa jumlah siswa SD/MI pada tahun 2000/2001 sebanyak 228.366 orang. Jika diestimasikan bahwa sekitar 5\% - 10\% (berdasarkan penelitian Stanford Institute), maka diperkirakan anak yang mengalami kesulitan belajar berkisar antara 11.418 sampai 22.837 orang. Jumlah anak berkesulitan belajar akan semakin meningkat terutama setelah kriteria adaptabilitas sosial digunakan dalam menentukan anak tunagrahita selain taraf intelegensi, sehingga anak-anak yang semula dianggap sebagai tunagrahita ternyata termasuk anak berkesulitan belajar.

Peran sekolah dan orang tua dalam mendeteksi secara dini dan menciptakan lingkungan yang kondusif sangatlah berdampak dalam perkembangan anak yang mengalami kesulitan belajar ini. Namun pada kenyataannya seringkali banyak pihak tidak 
mengetahui bahwa anak-anak tersebut mengalami kesulitan belajar, bahkan tidak mengerti apa itu kesulitan belajar. Karena yang nampak adalah rendahnya nilai mata pelajaran tertentu, maka seringkali mereka berpendapat bahwa anak tersebut "bodoh", malas, tidak memiliki motivasi belajar dan anggapananggapan negatif lainnya. Bahkan setelah didiagnosis oleh para ahli pun, seringkali tetap tidak mengerti apa dan bagaimana itu learning disabilities atau kesulitan belajar. Mereka bahkan semakin heran dengan tingginya nilai hasil test IQ anak tersebut sementara di sekolah prestasi anaknya cenderung rendah. Disinilah letak pentingnya pemahaman dan kemampuan semua pihak dalam membantu menangani anak-anak dengan kesulitan belajar.

Di luar negeri, sebenarnya telah banyak penelitian yang dilakukan mengenai efek bimbingan kolaboratif terhadap berbagai aspek perkembangan siswa, diantaranya yang dilakukan oleh Elizabeth W. Simmons yang melakukan penelitian mengenai dampak dari kolaborasi antara sekolah-rumah-komunitas terhadap pencapaian akademik siswa. Hasil penelitiannya menunjukkan bahwa kolaborasi yang dilakukan berhasil mencapai tujuan peningkatan pencapaian akademik siswa.

Namun di Indonesia, bimbingan kolaboratif antara pihak sekolah dengan orang tua bukanlah sesuatu yang umum dilakukan. Orang tua seringkali berpikir bahwa sekolah lah yang memegang tanggung jawab utama terhadap perkembangan semua aspek anak mereka, terutama aspek akademik. Selain itu pihak sekolah tidak menyediakan sarana dan prasarana untuk melakukan bimbingan kolaboratif. Mereka tidak memiliki model atau acuan yang jelas untuk melaksanakan bimbingan tersebut, sehingga bila bimbingan tersebut dilakukan hanya sebatas tindakan spontan yang tidak terstruktur atau terencana.

\section{B. HASIL DAN PEMBAHASAN}

\section{Bimbingan Bagi Siswa Yang Mengalami Learning Disabilities}

Layanan bimbingan dan konseling yang dikhususkan bagi anak dengan kesulitan belajar harus disesuaikan dengan karakteristik mereka. Ada beberapa tahapan atau prosedur pengembangan kurikulum konseling (VanZandth,2001:76), secara umum, yaitu:

a. Berdasarkan daftar yang telah dibuat sebagai hasil dari asesmen kebutuhan, menentukan hasil yang akan dicapai oleh siswa yang menjawab asesmen kebutuhan tersebut.

b. Mengembangkan daftar prioritas capaian siswa tersebut, dengan pengawasan dan supervisi dari para ahli

c. Mengidentifikasi format instruksional untuk mencapai target yang telah ditentukan. Buatlah aktivitas ekstrakulikuler disamping aktivitas dalam kelas.

d. Membuat bagan rancangan yang berisi kapan,dimana dan bagaimana suatu target akan diperkenalkan, dikembangkan bahkan dipaksakan pelaksanaannya

e. Secara berkala memperbaharui kurikulum konseling berdasarkan feedback yang didapat dari guru maupun dari siswa

Inti keberhasilan pelaksanaan layanan bimbingan dan konseling anak berkebutuhan khusus (termasuk anak dengan learning disabilities) adalah terjadinya perubahan prilaku positif pada diri anak berkebutuhan khusus tersebut., sebagaimana yang telah ditetapkan atau dirumuskan sebelumnya melalui indikator-indikator yang menyertainya, terutama dari perilaku-perilaku nyata yang ditampilkan dalam kehidupan sehari-hari sesuai dengan kawasan perilaku, tahapan perkembangan, dan predisposisi yang menyertainya, serta nilai-nilai yang mendasari perilaku tersebut.

Secara umum kriteria keberhasilan dalam bimbingan dan konseling terletak pada sejauh mana kegiatan bimbingan dan konseling yang (intervensi) yang telah dilakukan mampu:

a. Memberikan arah yang jelas bagi kemudahan belajar pada anak berkebutuhan khusus sesuai aspek yang ingin dikembangkan.

b. Mendorong berfungsinya lingkungan sehingga mampu menjadi media yang 
bermakna bagi belajar dan berkembang ke arah yang lebih baik.

c. Menjamin keserasian interaksi dinamis pribadi-lingkungan secara bermakna bagi tercapainya fungsi pengarahan diri, pengaturan diri, aktualisasi diri, dan pembaharuan diri.

\section{Bimbingan Kolaboratif}

Kolaborasi adalah suatu proses dimana dua individu atau juga dua kelompok ataupun lebih bekerja bersama untuk mencapai tujuan bersama, serta saling menguntungkan satu sama lain (Allen,1994).

Ada beberapa karakteristik dan persyaratan mendasar bagi suatu hubungan kolaboratif (Allen,1994 \& Simmons), yaitu : saling menghormati, saling percaya, komunikasi yang terbuka \& jelas, flexibility, kompromi, berbagi, menerima ide orang lain, mendengar secara aktif, serta mau mengambil resiko.

Agar hubungan kolaboratif dapat berjalan maka semua partisipan harus memiliki visi dan misi yang sama. Motivasi untuk menyamakan misi biasanya didasarkan pada kesamaan kebutuhan untuk mencapai kesepakatan atau menyelesaikan permasalahan yang dirasakan bersama. Memulai dan menjaga hubungan kolaboratif dengan berbagai pihak yang berkepentingan sebenarnya merupakan salah satu tugas yang perlu dilakukan oleh konselor sekolah

\section{Manfaat Bimbingan Kolaboratif}

Ada banyak keuntungan yang didapat dari proses kolaborasi yang dilakukan, diantaranya adalah (NPTAC;5):

a. Meningkatkan pemahaman mengenai keadaan siswa melalui berbagai sudut pandang yang berbeda

b. Meningkatkan kemampuan untuk mengatasi hambatan secara lebih luas

c. Membagikan berbagai strategi instruksi kepada sesama anggota kelompok kolaboratif

d. Berbagi ide mengenai bagaimana memenuhi kebutuhan siswa

e. Meningkatkan konsistensi dan komunikasi f. Memaksimalkan waktu yang dimiliki melalui kerjasama dan pengorganisasian sumberdaya dan personel yang ada

g. Saling berbagi keputusan yang diambil

h. Berbagi tanggung jawab

\section{Strategi Bimbingan Kolaboratif}

Pihak sekolah sebenarnya memiliki tanggung jawab untuk melakukan segala hal yang memungkinkan untuk menjalin kerjsama antara pihak sekolah dan rumah. Ada banyak strategi yang dapat diterapkan untuk menciptakan kolaborasi yang baik dengan para orang tua, beberapa diantaranya bahkan berhasil digunakan untuk mengikat hubungan dengan orang tua yang cenderung menolak untuk bekerjasama (NPATC:13)

a. Memahami dan memberdayakan orang tua

1) Melihat dari sudut pandang orang tua. Misalnya apakah ada masalah-masalah tertentu yang menghambat keterlibatan orang tua

2) Kenali kelebihan orang tua dan menggunakannya untuk mengembangkan anak mereka

3) Referensikan kelompok atau komunitas tertentu yang dapat dimasuki oleh orang tua

b. Gunakanlah ketrampilan mendengar secara aktif untuk meningkatkan komunikasi dengan orang tua

1) Melakukan "kontak-mata" dan menggunakan kata "saya mengerti"

2) Tunggu dan memberikan jawaban setelah orang tua selesai berbicara

3) Saat menjawab, awali dengan kalimat yang menjelaskan apa yang kehawatiran orang tua. Ini sekaligus berfungsi untuk klarifikasi terhadap apa yang telah dijabarkan oleh orang tua.

4) Perhatikan "bahasa tubuh" dan emosi yang ditampilkan oleh orang tua.

c. Gunakan teknik komunikasi verbal yang efektif

1) Selalu mengontrol keseimbangan anatar pemberian komentar negative dan positif yang disampaikan. 
2) Gambarkan tingkah laku anak dan jangan memberikan penilaian.

3) Gunakan kata "saya" sehingga orang tua tidak merasa dipersalahkan

4) Jabarkan istilah atau kalimat yang asing. Bacakan hasil test dan jelaskan apa maknanya.

d. Gunakan berbagai strategi untuk mengatasi orang tua yang marah

1) Jika orang tua berbicara dengan suara keras maka mintalah mereka untuk berbicara dengan lebih pelan.

2) Hindari perdebatan, hal ini akan membuat orang tua hanya membela diri dan menurunkan minat interaksi orang tua

3) Lakukan beberapa langkah berikut :

a) Menulis apa yang disampaikan orang tua

b) Membangkan pertanyaan dari apa yang disampaikan orang tua

c) Meminta penjelasan bila apa yang disampaikan orang tua tidak jelas atau terlalu luas

d) Memperlihatkan catatan yang telah dibuat dan meminta orang tua untuk melengkapi kekurangan yang ada

e) Menulis saran atau solusi pemecahan masalah

e. Maksimalkan keterlibatan orang tua dengan cara meminta masukan dari orang tua secara berkala

1) Menjaga komunikasi secara teratur dengan orang tua, baik melalui telephon, buku penghubung dll

2) Mengundang orang tua untuk berpartisipasi dalam pengembangakn program individual anak mereka maupun proses pemecahan masalah lainnya

3) Mengatur pertemuan pada waktu yang memungkinkan bagi orang tua. Menjelaskan lama waktu yang dibutuhkan serta tujuan pertemuan tersebut. pastikan waktu yang direncanakan mencukupi.

4) Mempersiapkan jawaban atas pertanyaan yang sering diajukan oleh orang tua yang memiliki anak dengan learning disabilities

5) Membagikan strategi yang dapat dilakukan oleh orang tua dalam menjelaskan apa itu learning disabilities kepada anak mereka.

Dengan berbagai strategi diatas yang diterapkan secara konsisten maka diharapkan hasil yang dapat dicapai adalah sebagai berikut:

a. Orang tua memiliki akses untuk memperoleh informasi yang mereka perlukan, memudahkan pengambilan keputusan dan menemukan sumber lain yang dapat membantu mereka.

b. Orang tua berperan aktif dalam pendidikan anak mereka.

c. Orang tua berperan dalam pengambilan keputusan yang berkenaan dengan pendidikan anak mereka

d. Anak mendapatkan kejelasan, dari rumah maupun sekolah mengenai apa yang diharapkan terhadap mereka secara akademik maupun tingkah laku.

e. Terjalinnya komunikasi berkelanjutan antara pihak sekolah dan rumah.

\section{Model Bimbingan kolaboratif}

Ada beberapa model kolaboratif yang digunakan saat ini (NPTAC;5). Semua model tersebut memiliki nilai positif dan tingkat efektifitas yang cukup baik. Masing-masing model memiliki fungsi spesifik dan berpotensi meningkatkan hubungan kolaboratif antara orang tua dan guru. Beberapa model yang banyak digunakan adalah :

a. Policy groups

Kelompok (grup) baik lokal daerah tertentu maupun nasional yang biasanya terdiri dari para professional dan orang tua yang bersama-sama bertujuan memecahkan suatu permasalahan tertentu.

\section{b. Parent-faculty partnership programs}

Program pelatihan bagi para calon guru untuk berkolaborasi dengan para professional dan orang tua yang memiliki disabilitas tertentu

c. Co-training 
Professional pendidikan khusus dan para orang tua dapat berpartisipasi di sekolah ataupun lembaga lain dengan memberikan pelatihan,berkomunikasi,kolaborasi, intervensi perilaku yang positif maupun hal lain terhadap staf sekolah maupun orang tua lainnya

\section{d. Material review}

Orang tua (baik perorangan maupun kelompok) dapat mereview materi yang dikembangkan oleh para professional, dengan tujuan agar materi tersebut dapat memenuhi kebutuhan para orang tua yang mengikuti pelatihan tertentu.

e. Parents as trainers

Orang tua dapat melatih staf sekolah berbagai strategi yang bertujuan meningkatkan keterlibatan orang tua lainnya.

f. Professionals as trainers

Para professional dapat berdiskusi dengan kelompok orang tua mengenai cara-cara efektif yang dapat dilakukan oleh mereka untuk meningkatkan keterlibatannya dalam pendidikan dan mendukung perkembangan anak-anak mereka.

g. Parent training and information centers/community parent resource centers model

Sebuah lembaga yang memberikan informasi dan pelatihan yang bertujuan membantu orang tua. Keuntungan lain bagi orang tua adalah dapat berhubungan dengan orang tua lain yang memiliki permasalahan yang sama, sedangkan bagi para professional kegiatan ini dapat memberikan informasi mengenai apa yang dibutuhkan oleh para orang tua sebenarnya dan bagaimana pendapat mereka terhadap kegiatan tersebut.

\section{Implikasi Bimbingan kolaboratif Yang Efektif}

Dalam menjalin hubungan dengan orang tua, sekolah perlu menyelenggarakan sebuah kerjasama yang yang efektif dan efisien. Pertemuan antara orang tua dan guru dapat menjadi sebuah jembatan antara kondisi rumah dan sekolah. Baik orang tua maupun guru seringkali merasa khawatir saat akan menghadiri pertemuan semacam itu. Orang tua umumnya khawatir terhadap laporan guru mengenai kondisi dan perkembangan anak mereka di sekolah; sedangkan para guru ataupun pihak sekolah umumnya khawatir mengenai kemungkinan munculnya reaksi negatif dari orang tua bila mereka mengetahui kondisi anak mereka yang tidak sesuai harapan.

Pertemuan orang tua dengan pihak sekolah hendaknya dianggap sebagai suatu wahana untuk mengoptimalkan perkembangan anak, oleh karena itu sejak awal pihak sekolah harus memberikan pengetahuan dan pemahaman kepada para orang tua bahwa pertemuan yang dirancang semuanya memiliki tujuan yang positif, yaitu semata-mata demi kepentingan anak.

Pihak sekolah hendaknya menyelenggarakan kerjasama dan pertemuan dengan pola sejajar, pola hubungan antara dua individu yang setara. Guru hendaknya memperlihatkan perhatian mereka terhadap anak dan menghargai orang tua, tidak "menggurui" dan tidak bersikap merasa paling tahu mengenai kondisi anak mereka. Berbagai kesulitan yang dialami anak hendaknya dibicarakan dengan suasana tenang, jelas dan menghindari istilah-istilah teknis yang sekiranya tidak dipahami oleh orang tua. Para orang tua umumnya akan dapat menerima penjelasan guru bila disertai bukti ataupun data yang jelas, oleh karena itu pihak sekolah hendaknya mengumpulkan informasi sebanyak mungkin sebelum menyelenggarakan sebuah pertemuan dengan orang tua. Sehingga dengan demikian orang tua dapat dengan mudah menerima dan memahami kendala yang dialami oleh anak mereka. Mereka tidak akan bersikap defensif dan menyangkal serta menolak penjelasan guru. Sehingga dengan demikian, diharapkan kerjasama yang terjalin dapat memberikan manfaat sebesar mungkin bagi optimalisasi perkembangan anak.

Para orang tua pada umumnya ingin mengetahui apa yang dapat mereka lakukan, perlakuan atau bantuan seperti apa yang dibutuhkan oleh anak-anak mereka yang mengalami kesulitan belajar. Menurut 
Abdurrahman (2009: 109 dikutip dari Mercer, 1979: 102) ada beberapa aktivitas yang dapat dikerjakan oleh orang tua di rumah untuk membantu anak mereka, yaitu :

\section{a. Melakukan observasi perilaku anak}

Orang tua mempunyai lebih banyak waktu untuk bergaul dan berhubungan dengan anak sehingga mereka dapat secara lebih leluasa melakukan pengamatan atau observasi berbagai tingkah laku anak, bila dibandingkan dengan guru, dokter ataupun konselor. Oleh karena itu, melatih orang tua untuk mengembangkan keterampilan melakukan observasi perilaku anak merupakan kegiatan yang sangat bermanfaat bagi upaya membantu anak berkesulitan belajar. Hasil observasi tersebut kemudian dapat dileporkan kepada guru,dokter,konselor maupun pihak yang kompeten lainnya sebagai bahan pertimbangan dalam memecahkan permasalahan yang yang dialami oleh anak. Ada banyak hal yang dapat diobservasi oleh orang tua dirumah, terutama yang berkaitan dengan kebiasan-kebiasaan anak di rumah, seperti kebiasan makan, pola tidur anak, jenis permainan yang disukai, pola belajar dan lain sebagainya.

\section{b. Memperbaiki perilaku anak}

Anak berkesulitan belajar seringkali juga memperlihatkan adanya masalah perilaku. Beberapa permasalahan perilaku yang paling umum diantaranya adalah hiperaktivitas, kecanggungan, dan emosi yang labil. Untuk memperbaiki perilaku tersebut, orang tua dapat mengikuti petunjuk dan arahan yang diberikan oleh para ahli (psikolog, konselor, guru ataupun dokter). Dengan demikian upaya perbaikan perilaku dapat dilakukan secara bersama, baik oleh pihak luar (di tempat terapi, dan di sekolah misalnya) maupun oleh orang tua.

\section{c. Mengajar anak}

Masyarakat umumnya memandang bahwa tugas orang tua di rumah adalah untuk menanamkan kebiasaan dan tradisi yang berlaku dalam lingkungan sosialnya, sehingga orang tua diharapkan mengajarkan norma dan keterampilan sosial. Sedangkan mengenai pengajaran akademik, ada dua pandangan yang beredar di masyarakat; pandangan yang pertama adalah pandangan yang tidak memperbolehkan orang tua mengajarkan bidang akademik kepada anak di rumah, sementara pendangan yang kedua, adalah pandangan yang menganjurkan agar orang tua mengajarkan bidang akademik dirumah.

Ada beberapa hal yang dapat dilakukan oleh para professional untuk mempererat hubungan kolaboratif dengan para orang tua, diantaranya adalah (Alliance:8):

a. Menepati janji dan menjamin kerahasiaan

Profesional dapat meningkatkan rasa percaya dengan memberitahukan informasi apa saja yang akan dirahasiakan dan apa yang akan dibagi bersama anggota lainnya. Selain itu juga dengan selalu meminta ijin dulu saat akan membicarakan mengenai anak mereka

b. Bersifat membantu dan jujur mengenai potensi dan kelebihan yang dimiliki anak mereka

Profesional tidak boleh menahan informasi dan bersikap jujur walaupun itu merupakan informasi yang menyakitkan bagi orang tua, atau juga bila ia tidak memiliki jawaban yang tepat atas pertanyaan ataupun kebutuhan orang tua. Bila hal itu terjadi maka professional harus menghubungkan dengan ahli lain yang sesuai.

c. Membantu orang tua untuk mengidentifikasi kekuatannya

Terkadang orang tua tidak memahami bahwa apa yang meraka lakukan seharihari memiliki efek penting dalam keseluruhan program. Profesional dapat secara berkala dapat memberikan informasi mengenai kemajuan anak mereka dengan menjabarkan efektifitas intervensi yang dilakukan oleh orang tua.

d. Membantu orang tua untuk mengidentifikasi pilihan yang ada

Staf sekolah dapat membantu orang tua untuk mengidentifikasi orang tua untuk mengidentifikasi berbagai pilihan dan solusi yang tersedia bagi mereka serta mendukung mereka untuk mampu mengambil keputusan sendiri. 
e. Mengajarkan ketrampilan pemecahan masalah

Profesional dapat mengajarkan ketrampilan pemecahan masalah kepada orang tua serta mendorong mereka untuk menemukan solusi kreatif bagi masalah mereka selanjutnya. Hal ini mungkin tidak dapat dilakukan pada semua jenis orang tua.

f. Memperlakukan orang tua sebagai partner yang sejajar

Secara tradisonal para professional memegang peranan penting dalam hubungan kolaboratif, hal ini memudahkan mereka untuk mengajak orang tua untuk memasuki sistem yang mereka bangun.

g. Mempertimbangkan dan bersikap fleksibel terhadap cara pandang orang tua

Professional harus mengembangkan kemampuan untuk merubah cara pandang mereka dan menyesuaikan dengan kebutuhan anak dan orang tua secara lebih luas.

h. Mempertimbangkan kecenderungan keluarga dalam semua perencanaan

Profesional harus harus mampu menggunakan kekuatan dan kelebihan yang dimiliki keluarga agar dapat mencapai tujuan bersama. Orang tua akan merasa lebih terbantu bila mereka mengetahui langkah apa yang harus mereka lalui.

i. Mendukung orang tua dalam membuat keputusan mengenai anak mereka

Terkadang banyak orang tua perlu terus diingatkan bahwa mereka adalah pengambil keputusan terbaik bagi anak mereka dan bahwa masukan dari mereka sangatlah berharga.

j. Mempersiapkan segala detil yang diperlukan untuk setiap pertemuan

Akan sangat menguntungkan bila professional bisa bersikap fleksibel mengenai waktu dan lokasi pertemuan dengan para orang tua.

k. Membuat perencanaan tentang keterlibatan orang tua dalam sebuah sistem

Professional dapat meningkatkan hubungan kolaboratif dengan meminta orang tua untuk bersama-sama dengan mereka mengembangkan peraturan dan prosedur sistem yang akan dilakukan.

Para orang tua juga dapat melakukan berbagai hal untuk membangun dan menjaga hubungan kolaboratif dengan para professional (NPTAC;10). Biasanya orang tua memulai hubungan kolaboratif dengan berasumsi bahwa para professional akan melakukan yang terbaik bagi anak mereka dan bagi diri mereka sendiri. Orang tua dapat berkontribusi untuk mensukseskan hubungan kolaboratif dengan melakukan berbagai hal, diantaranya adalah :

a. Mengenali komitmen dan kemampuan para professional berkaitan dengan anak mereka yang mengalami difficulties Sangatlah penting bagi orang tua untuk memahami kemampuan guru dan terapis anak mereka serta mengetahu bagaimana komitmen mereka dalam memenuhi kebutuhan anak mereka.

b. Berterima kasih terhadap para professional yang telah membantu mereka

Seringkali para professional bekerja jauh melebihi apa yang seharusnya mereka lakukan dalam membantu sebuah keluarga. Orang tua perlu mengapresiasi bila hal tersebut terjadi.

c. Menyadari bahwa terkadang para professional dibatasi oleh system tempat mereka bekerja

Para professional seringkali berharap mereka dapat melakukan sesuatu yang lebih dari apa yang dapat mereka berikan. Hal ini tidak selalu berarti bahwa mereka tidak memiliki kemampuan untuk melakukan hal tersebut. Para orang tua perlu memahami siapakah di dalam suatu sistem orang yang paling berkuasa dalam mengambil sebuah keputusan.

d. Memperkuat dirumah apa yang telah dipelajari oleh anak mereka di sekolah Orang tua perlu bersikap positif terhadap apa yang didapatkan anak dari sekolah, karena pada dasarnya anak-anak menyadari bagaimana sikap dan cara pandang orang tua terhadap sekolah mereka. 
e. Mau mempertimbangkan dan bersikap fleksibel terhadap cara pandang para professional

Perlu diingat bahwa tidak ada stu orang professional pun yang mampu memahami kebutuhan anak yang mengalami disabilitas sama dengan cara pandang orang tua. Para professional tidak otomatis mengetahui dan memahami apa yang telah dialami oleh orang tua dengan anak-anak mereka.

f. Bersikap jujur

Sangatlah penting bagi orang tua untuk berbicara jujur bila mereka tidak memahami apa yang disampaikan oleh para ahli. Tidak perlu merasa malu atau takut, serta orang tua berhak mengemukakan pendapat bila mereka merasa tidak setuju dengan pendapat para ahli.

g. Menepati janji

Saat orang tua telah membuat komitmen maka mereka memegang tanggung jawab untuk menepatinya. Hubungan kolaboratif akan bisa berjalan dengan baik bila ada sikap saling mempercayai.

h. Berkomitmen untuk menemukan solusi bila terjadi ketidaksepakatan

Terkadang ketidaksepahaman tidak bisa dihindari. Ini semata hanya perbedaan pendapat saja dan bukan ketidaksesuain pribadi masing-masing pihak. Kolaborasi yang efektif adalah yang semata-mata bertujuan mencari solusi.

i. Selalu mengingat bahwa hidup penuh dengan kompromi

Kebanyakan orang tua khawatir anaknya tidak memperoleh layanan ataupun treatment seperti yang seharusnya. Namun sebenarnya pada kenyataannya setiap hari anak-anak akan menghadapi kompromikomprominya sendiri. Tetap fokus pada tujuan akhir akan mempermudah kolaborasi yang dijalin.

Dalam menjalin hubungan dengan orang tua, sekolah perlu menyelenggarakan sebuah kerjasama yang yang efektif dan efisien. Pertemuan antara orang tua dan guru dapat menjadi sebuah jembatan antara kondisi rumah dan sekolah. Baik orang tua maupun guru seringkali merasa khawatir saat akan menghadiri pertemuan semacam itu. Orang tua umumnya khawatir terhadap laporan guru mengenai kondisi dan perkembangan anak mereka di sekolah; sedangkan para guru ataupun pihak sekolah umumnya khawatir mengenai kemungkinan munculnya reaksi negatif dari orang tua bila mereka mengetahui kondisi anak mereka yang tidak sesuai harapan.

Pertemuan orang tua dengan pihak sekolah hendaknya dianggap sebagai suatu wahana untuk mengoptimalkan perkembangan anak, oleh karena itu sejak awal pihak sekolah harus memberikan pengetahuan dan pemahaman kepada para orang tua bahwa pertemuan yang dirancang semuanya memiliki tujuan yang positif, yaitu semata-mata demi kepentingan anak.

Pihak sekolah hendaknya menyelenggarakan kerjasama dan pertemuan dengan pola sejajar, pola hubungan antara dua individu yang setara. Guru hendaknya memperlihatkan perhatian mereka terhadap anak dan menghargai orang tua, tidak "menggurui" dan tidak bersikap merasa paling tahu mengenai kondisi anak mereka. Berbagai kesulitan yang dialami anak hendaknya dibicarakan dengan suasana tenang, jelas dan menghindari istilah-istilah teknis yang sekiranya tidak dipahami oleh orang tua. Para orang tua umumnya akan dapat menerima penjelasan guru bila disertai bukti ataupun data yang jelas, oleh karena itu pihak sekolah hendaknya mengumpulkan informasi sebanyak mungkin sebelum menyelenggarakan sebuah pertemuan dengan orang tua. Sehingga dengan demikian orang tua dapat dengan mudah menerima dan memahami kendala yang dialami oleh anak mereka. Mereka tidak akan bersikap defensif dan menyangkal serta menolak penjelasan guru. Sehingga dengan demikian, diharapkan kerjasama yang terjalin dapat memberikan manfaat sebesar mungkin bagi optimalisasi perkembangan anak.

Dalam membangun suatu bimbingan kolaboratif, ada banyak hal yang harus diperhatikan. Hal ini bukan semata-mata untuk memastikan bahwa kedua belah pihak mau berpartisipasi tetapi juga agar bimbingan yang 
dilakukan dapat berhasil mencapai tujuan secara efektif.

Ada beberapa hal yang harus diperhatikan agar bimbingan kolaboratif dapat berjalan secara efektif (Rutgers, 2009: 3) yaitu :

a. Kolaborasi membutuhkan waktu, untuk :

1) Untuk membangun kepercayaan

2) Untuk memahami tanggung jawab dan aturan

3) Untuk mengajukan dan menjawab pertanyaan

4) Untuk memberikan informasi yang diperlukan untuk mengambil suatu keputusan

b. Kolaborasi haruslah berdasarkan rasa percaya dan ditunjukan :

1) Dengan menghadiri pertemuan secara berkala

2) Dengan memastikan bahwa setiap orang mendapatkan informasi yang sama

3) Dengan berbagi cara pandang yang berbeda

4) Dengan memastikan kevalidan cara pandang yang berbeda

c. Kolaborasi berarti bahwa kontrol haruslah di tanggung bersama dan berdasarkan :

1) Tidak ada satu orang pun yang mampu menjawab semua hal secara bersamaan

2) Kuncinya adalah keseimbangan antara memberi dan menerima

\section{SIMPULAN}

Kesulitan belajar atau "Learning disabilities" adalah hambatan / gangguan belajar pada anak dan remaja yang ditandai oleh adanya kesenjangan yang signifikan antara taraf intelegensi dan kemampuan akademik yang seharusnya dicapai. Hal ini disebabkan oleh gangguan di dalam sistem saraf pusat otak (gangguan neurobiologis) yang dapat menimbulkan gangguan perkembangan seperti gangguan perkembangan bicara, membaca, menulis, pemahaman, dan berhitung. Bila tidak ditangani dengan baik dan benar akan menimbulkan berbagai bentuk gangguan emosional (psikiatrik) yang akan berdampak buruk bagi perkembangan kualitas hidupnya di kemudian hari.

Kepekaan orangtua,guru di sekolah serta orang-orang di sekitarnya sangat membantu dalam mendeteksinya, sehingga anak dapat memperoleh penanganan dari tenaga profesional sedini dan seoptimal mungkin, sebelum menjadi terlambat.Kesulitan Belajar kadang-kadang tidak terdeteksi dan tidak dapat terlihat secara langsung. Setiap individu yang memiliki kesulitan belajar sangatlah unik. Seperti misalnya, seorang anak "dyslexia", yang sulit membaca,menulis dan mengeja, tetapi sangat pandai dalam matematika.Pada umumnya, individu dengan kesulitan belajar memiliki intelegensi minimal rata-rata dan bahkan seringkali diatas rata-rata.

Tidak ada seorang ahli yang mampu memahami kebutuhan yang kompleks yang dimiliki anak dengan learning disabilities. Kolaborasi merupakan kunci kesuksesan bagi pengembangan segala aspek yang dimiliki siswa. Pada intinya, kolaborasi merupakan proses kerjasama untuk memecahkan berbagai permasalahan yang muncul. Kolaborasi dapat dilakukan dalam berbagai situasi dan kondisi.

Bimbingan kolaboratif bertujuan untuk mendukung perkembangan sosial dan emosional anak-anak secara umum. Program utamanya adalah melalui pemberian pengetahuan bagi para orang tua (parent education) yang biasanya dilakukan oleh konselor sekolah. Program parent education merupakan salah satu strategi yang paling efektif uktuk menangani berbagai permasalahan yang dialami oleh anak dan remaja.

\section{DAFTAR PUSTAKA}

Abdurrahman,M. (2009) Pendidikan Bagi Anak Berkesulitan Belajar. Jakarta: PT Rineka Cipta

Allen,J.M. (1994) School Counselors Collaborating For Student Success. Eric Digest. EDO-CG-94-27 (June 1994)

NJCLD (2010) Comprehensive Assessment and Evaluation of Students With Learning Disabilities (Juni,2010).

Simmons,E.W. The Impact of 
Home/School/Community Collaboration On Student Achievemnet: An Analysis of Reading Renaissance

VanZandt,Z. \& Hayslip,J (2001). Developing Your School Counseling Program. A Handbook for Systemic Planning. USA. Brooks/Cole Thomson Learning (2009). Strategies for Effective Collaboration with Parents, Schools and Community Members. Rutgers The State University Of New Jersey. (Feb.26,2009 \& Maret 17,2009 \& April 7,2009) 